\title{
Perioperative and postoperative fluid management in pediatric cardiac surgery
}

\author{
Abstract \\ The fluid fluid management plays a vital role in establishing and maintaining cellular \\ homeostasis in pediatric cardiac surgery. Goals of optimizing fluid therapy to manange \\ tissue perfusion, heart rate, hemoglobin, and oxygen saturation in this patients during \\ perioperatively and postoperatively.
}

Volume 4 Issue 5 - 2016

\author{
Türkan Kudsioglu, Filizizgi Coșkun, Nihan \\ Yapıcı \\ Siyami Ersek Thoracic and Cardiovasculary Center, Department \\ of Anaesthesiology and Reanimation, Turkey
}

Correspondence: Türkan Kudsioglu, Siyami Ersek Thoracic and Cardiovasculary Center, Department of Anaesthesiology and Reanimation, Istanbul-Turkey, Tel 905325935934 , Email turkancoruh@gmail.com

Received: March 04, 2016 | Published: April 05, 2016

\section{Introduction}

Perioperative and postoperative fluid management in pediatric cardiac surgery vary according to operation type, fluid needs and the condition of each patient adaptation. The gold standart of the fluid therapy is to use the correct fluid, to maintaine the electrolyte balance, and to provide cardiovascular stability, adequate organ perfusion and tissue oxygenation.

Pediatric patients were sorted according to their ages in seven different groups: premature newborns $(<38$ weeks gestational age), term newborns ( $>38$ weeks gestational age), neonate (0-30 days), infant ( 1 month -2 years), young child (2-6 years), child (6 - 12 years), and (g) adolescent (12 - 18 years). Newborn $75-80 \%$ of your body is water, fat and muscle content increase with age and this ratio decreases up to $60 \%$. The extracellular fluid in newborn is $45 \%$ of their body weight. This ratio becomes $30 \%$ by the age of 1 year, and $20 \%$ when they reach adolescent period. ${ }^{2}$ Newborns who have a large surface-to-weight ratio, higher total water content, limited renal ability to concentrate, greater insensible water loss, thin skin, and high blood flow can dehydrated quicker; ${ }^{3}$ therefore, the fluid management is very important for pediatric patients.

Holliday and Segar first identified the 4/2/1 rule based on calories and water consumptionin intravenous (IV) fluid therapy in children (Table 1). ${ }^{4}$ Newborn $(3-10 \mathrm{~kg}$ ) spends $100 \mathrm{kcal} / \mathrm{kg}$ calories, whereas, children $(10-20 \mathrm{~kg}) 1000 \mathrm{kcal}+50 \mathrm{kcal}$ per $/ \mathrm{kg}$ and $20 \mathrm{~kg}$ and over children $1500 \mathrm{kcal}+20 \mathrm{kcal} / \mathrm{kg}$. It is determined that daily energy requirement for potassium and chloride is $2 \mathrm{mEq} / 100 \mathrm{kcal} /$ day, for sodium $3 \mathrm{mEq} / 100 \mathrm{kcal} / \mathrm{day}$. These electrolytes are found in $5 \%$ dextrose and $0.45 \%$ normal saline, which is a hypotonic solution. However, in the perioperative period the use of hypotonic fluids increases the antidiuretic hormone secretion and may lead to hyponatremic encephalopathy, and temporary neurological damage. ${ }^{5}$

It is important to know the preoperative fluid deficit. Initially, preoperative fluid deficit was calculated by multiplying the hours of fasting by the fluid need calculated as per 4/2/1 rule and it was suggested that the half of the calculated volume should be given during the first hour of surgery, and the remaining half over the next 2 hours. ${ }^{6}$ Later this method was revised and the new practice was to give $25 \mathrm{ml} / \mathrm{kg}$ of fluid to children age of 3 and under during the first hour of surgery and $15 \mathrm{ml} / \mathrm{kg}$ to children 4 years and older. ${ }^{7}$
In 1999, American Society of Anaesthesiologists prepared guideline allowing clear fluid intake until 2 hours before anesthesia for patients undergoing elective surgery taking into consideration of the dehydrated children during secondary preoperative period (Table 2). ${ }^{8}$ There are protocols suggesting fasting period which is more than 2 hours (APA). However, the amount of fluid deficit after normal fasting cannot be exactly determined ${ }^{9}$ and there is no conclusive clinical findings indicating the degree of preoperative dehydration. In acute conditions, the child's weight loss may usually show the total water loss. Additionally, because renal function is the most important indicator of showing normal hydration, monitoring of urine output guides us in the evaluation and treatment of the fluid deficits. ${ }^{3}$ Decrease in blood pressure in pediatric patients is seen as a late finding of hypovolemia. If there is no finding of hypovolemia, dehydration should be corrected slowly with $0.9 \% \mathrm{NaCl} /$ Ringer Lactate. Depending on the severity of dehydration, hypovolemia should be treated with $10-20 \mathrm{ml} / \mathrm{kg}$ isotonic/ colloid in order to protect cardiac output and perfusion of organs. ${ }^{10}$

Table I Holliday and Segar' formula (4/2/I rule)

\begin{tabular}{lll}
$\begin{array}{l}\text { Weight } \\
\text { (kg) }\end{array}$ & $\begin{array}{l}\text { Hourly fluid } \\
\text { requirements }\end{array}$ & $\begin{array}{l}\text { Daily fluid } \\
\text { requirements }\end{array}$ \\
\hline $0-10 \mathrm{~kg}$ & $\begin{array}{l}4 \mathrm{ml} / \mathrm{kg} / \mathrm{h} \\
100 \mathrm{ml} / \mathrm{kg}\end{array}$ \\
$10-20 \mathrm{~kg}$ & $\begin{array}{l}40 \mathrm{ml} / \mathrm{saat}+2 \mathrm{ml} / \mathrm{kg} / \mathrm{h} \\
(\text { above } 10 \mathrm{~kg})\end{array}$ & $\begin{array}{l}1000 \mathrm{ml} / \mathrm{kg}+50 \mathrm{ml} / \mathrm{kg} \\
(\text { above } 10 \mathrm{~kg})\end{array}$ \\
$>20 \mathrm{~kg}$ & $\begin{array}{l}60 \mathrm{ml} / \mathrm{saat}+1 \mathrm{ml} / \mathrm{kg} / \mathrm{h} \\
\text { (above } 20 \mathrm{~kg})\end{array}$ & $\begin{array}{l}1500 \mathrm{ml} / \mathrm{kg}+25 \mathrm{ml} / \mathrm{kg} \\
\text { (above } 20 \mathrm{~kg})\end{array}$ \\
\hline
\end{tabular}

Table 2 Preoperative Fasting guidelines for elective surgery as American Society of Anaesthesiologists

\begin{tabular}{ll}
\hline Ingested material & Minimum fasting period $(\mathbf{h})$ \\
\hline Clear liquids & 2 \\
Breast milk & 4 \\
Infant formula & 4 (<3 months), 6 (>3 months) \\
Nonhuman milk & 6 \\
Ligth meal & 6 \\
\hline
\end{tabular}

\section{Perioperative fluid management}

In major surgical cases such as cardiac surgery, fluid passage to third space is $15-20 \mathrm{ml} / \mathrm{kg} / \mathrm{h}$, in premature infants it is $50 \mathrm{ml} / \mathrm{kg} / \mathrm{h}$. 
As young children and small infants have more extracellular volume compared to older children and adults, this translates into relatively more perioperative water loss. To protect homeostasis during the fluid resuscitation, crystalloid compound should be isotonic. Hyperchloremic metabolic acidosismay occur as a result of excess crystalloid compound. When ringer lactate is given, this is not seen. ${ }^{11}$ In fluid management towards the individual target, besides the use of crystalloid or colloid determining the optimum fluid deficit with monitoring is very important.In infants older than 1 month and children, fluid management should be made with isotonic fluids.

Blood glucose level should be controlled within normal limits when dextrose -free liquid is given during surgery. Before they are taken to the operating room, premature infants taking parenteral nutrition and fluids containing dextrose, low weight and high-risk newborns, and children having 3 hours longer duration of surgery such as cardiac surgery and receiving regional anesthesia carry high risk for hypoglycemia. Low concentration of (LRD $1 \%$ or LR $1 \frac{2}{2}$ D $2.5 \%$ ) should be given to these patients in perioperative period. ${ }^{12}$ Giving routine dextrose is not required except this group of children. However, hyponatremia, hyperchloraemic acidosis, hyperglycemia and hypoglycemia (blood glucose $<45 \mathrm{mg} / \mathrm{dL}$ ) should be avoided and glucose monitoring should be performed. Hypoglycemia, if not treated, causes temporary neurological disorders.Hyperglycemia with anaerobic metabolism causes accumulation of lactate, ischemia and hypoxia, decrease in intracellular $\mathrm{pH}$ and cell death. In addition, hyperglycemia causes dehydration, electrolyte abnormalities and osmotic diuresis. ${ }^{12}$

Choice of crystalloid or colloid should be assessed by the type of fluid deficit, coagulation cascade and its contribution to the microcirculation. ${ }^{13}$ Today, crystalloid is firstly preferred due to low cost and the lack of coagulation, anaphylactic and infection risk. After administration of a total of $30-50 \mathrm{ml} / \mathrm{kg}$ of crystalloid solution or colloid solutions, it is important to observe intravascular osmotic pressure. ${ }^{14}$ There are comparably fewer data to confirm the safety use of synthetic colloids (hydroxyethyl starches; HESs, gelatins and dextrans) in children than the data in in adults. Due to their high molecular weight and their degree of molar substitution, synthetic colloids have long term volume expander effect. Among colloids the natural one is albumin gold standard. The 5\% albumin solution is osmotically equivalent to plasma. ${ }^{15}$ Recently, HES (130/0:42/6:1) has been used for volume replacement in neonates and small infants in cardiac surgery. ${ }^{14,15}$ However, colloids have adverse effects on coagulation in children with bleeding problems and in some studies it is stated that they disrupt capillary leakage in septic newborns. ${ }^{15}$

Prime solution used during cardiopulmonary bypass (CPB) should be physiological. The CPB process itself leads to significant changes in erythrocytes, platelets and coagulation factors, dilution in plasma proteins and drug levels, in electrolyte. Therefore, the content and preparation of prime solution is important. Blood (erythrocytes), crystalloid and colloid solutions should be used as the prime CPB solution. Sufficient quantity is typically $200-300 \mathrm{ml}$ volume, while it is $240 \mathrm{ml}$ for the newborn. Factors such as the age of blood transfused in pediatric patients, the target hematocrit level according to the patient's pathology, the use of reduced-volume assembly line in CPB affect the duration of intraoperative and postoperative period.

The use of fresh blood during cardiac surgery in neonatal reduces the drainage in the ICU, systemic inflammatory markers, pulmonary and renal complications and shorten the duration of mechanical ventilation, inotropic support rate for 24-hour and the length of hospital stay. ${ }^{16,17}$ Because the use of old blood as the prime solution (12 days $>$ ) rises the lactate levels and causes tissue hypoxia development. ${ }^{18}$
Also, to reduce perioperative inflammation, leukocyte-free blood transfusion is recommended. ${ }^{19}$

Studies show that in recent years, in the new generated CPB machine, optimal $\mathrm{Hgb} 7 \mathrm{~g} / \mathrm{dl}$ levels are protected by miniature oxygenator and arterial filter systems in newborn patients without perioperative blood transfusion. ${ }^{20}$

\section{Postoperative fluid therapy}

Fluid therapy should compensate the basic metabolic requirements, gastrointestinal losses, and additional losses such as fever. Postoperative hyponatremia is the most common electrolyte disorder during this period, when hypotonic solutions are avoided; it can be prevented. ${ }^{6}$ The hematocrit level is important in newborn children with cyanotic congenital heart disease. If hematocrit level is $<25$ $\%$, blood should be transfused. Pediatric patients compared to adults have much higher oxygen consumption and cardiac output to blood volume ratio. During hemoglobin decrease, neonatal myocardium cannot compensate the reduced $\mathrm{O} 2$ carrying capacity by increasing cardiac output. Normal term neonatal hemoglobin levels (14-20g \%), respectively, begin to fall in subsequent months. ${ }^{21}$

Premature infants have higher ratio of fetal hemoglobin $(\mathrm{HbF})$ than term infants. HbF production decreases in a few months. In pediatric blood transfusions, possible complications are similar to adult patients'. Also, metabolic complications such as hypocalcemia, hyperkalemia and hypothermia can be developed most often. ${ }^{22}$

\section{Acknowledgments}

None.

\section{Conflicts of interest}

Author declare that there is no conflict of interest.

\section{Funding}

None.

\section{References}

1. Murat I, Dubois MC. Perioperative fluid therapy in pediatrics. Pediatr Anesth. 2008;18(5):363-370.

2. Friis-Hansen BJ, Holiday M, Stapleton T, et al. Total body water in children. Pediatrics. 1951;7(3):321-327.

3. Holliday MA, Ray PE, Friedman AL. Fluid therapy for children: Facts, fashions and questions. Arch Dis Child. 2007;92(6):546-550.

4. Oh TH. Formulas for calculating fluid maintenance requirements. Anesthesiology. 1980;53(4):351.

5. Montañana PA, Modesto I Alapont V, et al. The use of isotonic fluid as maintenance therapy prevents iatrogenic hyponatremia in pediatrics:A randomized, controlled open study. Pediatr Crit Care Med. 2008;9(6):589-597.

6. Furman E, Roman DG, Lemmer LA, et al. Specific therapy in water, electrolyte and bloodvolume replacement during pediatric surgery. Anesthesiology. 1975;42(2):187-193.

7. Berry F. Practical aspects of fluid and electrolyte therapy. In:Berry F (Ed.), Anesthetic management of difficult and routine pediatric patients. Churchill Livingstone, New York, USA; 1986. p. 107-135.

8. Practice guidelines for preoperative fasting and the use of pharmacologic agents to reduce the risk of pulmonary aspiration:Application to healthy patients undergoing elective procedures: a report by the American Society of Anaesthesiologist task force on preoperative fasting. Anesthesiology. 1999;90(3):896-905. 
9. Jacob M, Chappell D, Conzen P, et al. Blood volume is normal after preoperative overnight fasting. Acta Anaesthesiol Scand. 2008;52(4):522-529.

10. Bailey AG, McNaull PP, Jooste E, et al. Perioperative crystalloid and colloid fluid management in children:Where are we and how did we get here? Anesth Analg. 2010;110(2):375-390.

11. O'Malley CM, Frumento RJ, Hardy MA, et al. A randomized, doubleblind comparison of lactated Ringer's solution and $0.9 \% \mathrm{NaCl}$ during renal transplantation. Anesth Analg. 2005;100(5):1518-1524.

12. Leelanukrom R, Cunliffe M. Intraoperative fluid and glucose management in children. Paediatr Anaesth. 2000;10(4):353-359.

13. Paut O, Lacroix F. Recent developments in the perioperative fluid management for the paediatric patient. Curr Opin Anaesthesiol. 2006;19(3):268-277.

14. Sumpelmann R, Schurholz T, Marx G, et al. Haemodynamic, acid-base and electrolyte changes during plasma replacement with hydroxyethyl starch or crystalloid solution in young pigs. Paediatr Anaesth. 2000;10(2):173-179.

15. Tabbers MM, Boluyt N, Offringa M. Implementation of an evidencebased guideline on fluid resuscitation:Lessons learnt for future guidelines. Eur J Pediatr. 2010;169(6):749-758.
16. Gruenwald CE, McCrindle BW, Crawford-Lean L, et al. Reconstituted fresh whole blood improves clinical outcomes compared with stored component blood therapy for neonates undergoing cardiopulmonary bypass for cardiac surgery: a randomized controlled trial. $J$ ThoracCardiovasc Surg. 2008;136(6):1442-1449.

17. Ranucci M, Carlucci C, Isgrò G, et al. Duration of red blood cell storage and outcomes in pediatric cardiac surgery:an association found for pump prime blood. Crit Care. 2009;13(6):R207.

18. Schroeder TH, Hansen M. Effects of fresh versus old stored blood in the priming solution on whole blood lactate levels during paediatric cardiac surgery. Perfusion. 2005;20(1):17-19.

19. Miyaji K, Miyamoto T, Kohira S, et al. The influences of red blood cell transfusion on perioperative inflammatory responses using a miniaturized biocompatible bypass with an asanguineous prime. Int Heart J. 2009;50(5):581-589.

20. Koster A, Huebler M, Boettcher W, et al. A new miniaturized cardiopulmonary bypass system reduces transfusion requirements. $J$ Thorac Cardiovasc Surg. 2009;137(6):1565-1568.

21. Barcelona SL, Thompson AA, Cote CJ. Intraoperative pediatric blood transfusion therapy:A review of common issues. Part I:Hematologic and physiologic differences from adults;metabolic and infectious risks. Paediatr Anaesth. 2005;15(9):716-726 